\section{Who really counts in Iran's National Food Assistance Program? Lessons from multi-stakeholder processes in the wicked policy area of food security}

\author{
Quem importa realmente no Programa \\ Nacional de Assistência Alimentar do Irã? \\ Lições dos processos com múltiplos atores na \\ área política complexa de segurança alimentar
}

\section{¿A quién se tiene en cuenta realmente en el Programa Nacional de Asistencia Alimentaria en Irán? Lecciones sobre procesos con participación múltiple en la complicada área de política de seguridad alimentaria}

\author{
Mona Pourghaderi 1 \\ Nasrin Omidvar 1 \\ Amirhossein Takian 2 \\ Arlette Saint Ville 3 \\ Hannaneh Mohammadi Kangarani 4 \\ Hassan Eini-Zinab 1
}

doi: 10.1590/0102-311X00341820

\begin{abstract}
Multi-stakeholder processes - as a necessary part in the development of public policies - can provide diverse perspectives to inform and to improve food security policy-making. Iran's National Food Assistance Program (NFAP) is one of the major welfare programs in Iran that reduces food insecutiry to low-income households. This study aimed to identify and to categorize actual and potential stakeholders in NFAP using the stakeholder salience model. According to Mitchell's theory, stakeholders' attributes (power, legitimacy, and urgency) were assessed based on the nature of their interactions, roles, and level of engagement. Results revealed a number of significant but marginalized stakeholders, including Iranian Ministry of Health (office of community nutrition improvement), academia, center for food and nutrition research, target group, charities, and international organizations, who have not received any targeted organizational attention and priority to their claims. The unbalanced attention provided to some stakeholder groups characterized as "definitive" and "dominant" and ignoring some important ones will jeopardize long-term viability and undermine support for the program with inevitable declines in legitimacy. Understanding the change in the stakeholders' characteristics is the main variable to determine the allocation of organizational resources in response to different and rising stakeholders demands and possibly the projects outcomes. This will facilitate and enhance the possibility of knowledge exchange and learning, and greater trust among stakeholders during the food and nutrition policy-making process.
\end{abstract}

Correspondence

N. Omidvar

Department of Community Nutrition, School of Nutrition Sciences and Food Technology, Shahid Beheshti University of Medical Sciences.

Hafezi St., Farahzadi Blvd., Sanaat Sq., 7, Tehran 1981619573, Iran.

omidvar.nasrin@gmail.com

1 School of Nutrition Sciences and Food Technology, Shahid Beheshti University of Medical Sciences, Tehran, Iran.

2 School of Public Health, Tehran University of Medical Sciences, Tehran, Iran.

3 Faculty of Food and Agriculture, University of the West Indies, St. Augustine, Trinidad and Tobago.

4 School of Agricultural Engineering and Natural Resources,

Hormozgan University, Hormozgan, Iran. 


\section{Introduction}

Multi-stakeholder processes (MSPs) - essentially as a participatory decision-making process - brings a number of stakeholders to address wicked public policy issues that are intrinsically complicated and highly complex to explain and to solve 1,2. Stakeholders, i.e., any group or individuals who can affect or are affected by the decisions and actions made by policymakers 3 , are at risk of being marginalized by being identified and selected on an ad-hoc basis. In this way, bias will jeopardize long-term viability and undermine support for the process with inevitable declines in legitimacy 4 . For all these reasons, stakeholders' participation, through their direct or indirect involvement in decision-making is widely recognized as one of the principles of good governance and increasingly accepted as a component of policy-making processes $5,6,7$.

In policy and management sciences, stakeholder analysis is defined as a tool or set of tools for generating knowledge about actors - individuals and organizations - aiming to understand their behavior, intentions, interrelations, and interests. The influence and resources they bring - or could bring - to bear on decision-making or implementation processes have been also addressed 8 . The information generated from stakeholder analysis can be used to empower "marginalized stakeholders" in influencing decision making processes, to develop strategies for managing relevant stakeholders, and to facilitate meaningful interaction of diverse stakeholders in the implementation of projects 4,8. A typology of stakeholder analysis goes beyond identifying them; it provides methods for differentiating and categorizing the stakeholders 4,8. Compared with different approaches in "analytical categorizations" such as interest and influence, cooperation and competition, and cooperation and threat - typically using matrices 4 . The model developed by Mitchell - stakeholder salience model - describes how three attributes of power, legitimacy, and urgency can provide a more dynamic approach for categorizing stakeholders 9,10,11.

Iran's cabinet of ministers approved the National Food Assistance Program (NFAP) in July 2014. Deputy of Social Welfare in the Ministry of Cooperatives, Labor and Social Welfare (MCLSW) administers this program aiming to reduce food insecurity among low-income households who are supported by the Imam Khomeini Relief Foundation (IKRF) and the State Welfare Organization (SWO). The NFAP provides the recipients with an electronic card to purchase approved food items from authorized stores nationwide. Multiple and diverse stakeholders from public and private sectors have been engaged in this national program. Previous research has shown that decision-makers cannot attend all potential claims of all stakeholders 12,13 . This study aimed to identify and to categorize actual and potential stakeholders in NFAP with the stakeholder salience model focusing on their roles, level of engagement, and position. Furthermore, we tried to understand the mechanisms by which the authorities prioritized stakeholders' relationships. Knowing the types of stakeholders, and why managers respond to them, sets the stage for further research specifying how and under what circumstances the authorities can and should respond to the stakeholders.

\section{Conceptual framework}

Stakeholder salience model - synonymous with "Michelle's theory" 11 - was used to guide and to frame the stakeholder analysis in this case study. This approach determines stakeholders' salience by analyzing the degree to which decision makers give priority to competing stakeholder claims -based on the attributes of each stakeholders. In fact, this models considers stakeholders' salience a a function of one, or interaction between two or three following attributes: (1) the stakeholder's power to impose their will in the interaction by the use of coercive, utilitarian, or normative power sources; (2) the legitimacy of the stakeholder's actions or claims as being appropriate and desirable; and (3) the urgency associated with the stakeholder's claims 11,14. Also, it can help policy makers determine any imbalance or bias in program implementation and identify which stakeholder requires targeted organizational attention 9,14 . 


\section{Methods}

\section{Research design}

Using a case study research design and by conducting a stakeholder analysis 15,16 , we studied the stakeholders' characteristics and their classes in Iran's NFAP. Based on the typology of stakeholder analysis, the second level - followed by identifying stakeholders - consists of methods for differentiating and categorizing stakeholders 4. "Michelle's theory" was used as a dynamic model and Venn diagram, overlapping circles, to depict the logical relationships between two or more sets of items. This served to demonstrate the judgement on stakeholders' classes (latent, expectant, and definitive) and subclasses (dormant, discretionary, demanding, dominant, dependent, dangerous, and definitive) based on the three key attributes: power, legitimacy, and urgency 9,17,18 (Figure 1).

This model was used for studying stakeholders in the NFAP due to four reasons: (1) the existence of numerous and diverse stakeholders in this program with different levels of relevance and influence; (2) the characteristics are well suited to the food insecurity issues, where the most powerful stakeholders are able to advance their interests to the detriment of those who have legitimacy and might have an urgent claim 14,19,20,21; (3) some actors may have been marginalized as a result of power centralization 14; and (4) decision makers may be unaware of prioritizing stakeholders' relationships and the attention that they deserve 10,11 .

\section{Sample selection}

Firstly, key informants were consulted to develop an initial list of stakeholders 14 , in order to identify all stakeholders engaged in the NFAP, to reduce bias in the selection process, and to ensure diversity of study participants. Each stakeholder was asked to identify other stakeholders who should be included in the study, using snowball approach 22 . The final list was supported with secondary data; especially formal documents of the program. In total, 59 entities/organizations were identified as stakeholders in the NFAP. Subsequently, they were categorized into seven major groups: policy, credit, information, supply, e-Payment, non-governmental organization (NGOs), and target groups based on their similarities in functions, common goals, and joint actions around related activities (Box 1) 14. The Ministry of Cooperative, Labor, and Social Welfare (MCLSW), as the program designer and proposer, accompanied by the Ministry of Industry, Mines and Trade (MIMT) and the Ministry of AgricultureJihad (MAJ) that were responsible for developing the executive plan of the program. This ministries were recognized as the policy group with key roles in macro-executive decisions, including planning logistics and facilities related to food assistance. In the credit group, a total of 12 entities/organizations (Box 1) were identified, providing primary financial resources, determining, depositing and allocating program budgets in a connected manner. Entities/organizations in information group, accounted for $61 \%$ of all stakeholders. They provided information related to the recipients' family and personal identity, financial situation, and property ownership for MCLSW aiming to assess and to verify their entitlement. All stakeholders in the supply group were responsible for providing physical access and food items in the NFAP in coordination with each other. In total, three stakeholders, including TOSAN, Payment Service Providers, and SHAPARAK - as the e-Payment group - provided the platform for transactions and electronic payments in a joint action for ultimate users, due to special technical capabilities. In the NGO group, only one entity was identified and finally, low-income households supported by IKRF and SWO were categorized as the target group (the NFAP recipients).

These seven stakeholder groups were inclusive, that is, it was not necessary to define another stakeholder group. Then, study participants were collected from each group, who: (1) were directly involved in the formulation and the implementation of the program; (2) had the most information about the program; and (3) were willing to participate in the interviews. 
Box 1

Stakeholder groups and Institutions participating in the development and implementation of Iran's National Food Assistance Program (NFAP).

\begin{tabular}{|c|c|}
\hline STAKEHOLDER GROUP & ENTITY/ORGANIZATION \\
\hline Policy & $\begin{array}{c}\text { Ministry of Cooperative, Labor and Social Welfare, Ministry of Industry, Mine and Trade, } \\
\text { Ministry of Agriculture-Jihad }\end{array}$ \\
\hline Credit & $\begin{array}{l}\text { Petrochemical Factories, Refineries, Steel Factories, National Iranian Oil Refining and Distribution Company, } \\
\text { National Iranian Gas Company, Ministry of Petroleum, Ministry of Economic Affairs and Finance-Treasury } \\
\text { Administration, Central Bank of the Islamic Republic of Iran, Private Sector Banks, Public Sector Banks, Planning } \\
\text { and Budget Organization, Subsidy Targeting Organization }\end{array}$ \\
\hline Information & $\begin{array}{l}\text { Real Estate Registration Organization of Iran, Islamic Republic of Iran Police Force, Central Insurance of Iran, } \\
\text { Iranian National Tax Administration, State Administrative and Recruitment Organization, Iranian National } \\
\text { Organization for Civil Registration, Municipalities, Iran Water Resources Management Company, Regional } \\
\text { Water Companies, Iran Power Generation, Transmission and Distribution Company, Regional Grid Companies, } \\
\text { National Iranian Gas Company, Regional Gas Companies, Telecommunication Company of Iran, Regional } \\
\text { Telecommunication Companies, Subsidy Targeting Organization, Mobile Service Provider Companies, Central } \\
\text { Bank of the Islamic Republic of Iran, Information Technology Organization, Iran Post, Imam Khomeini Relief } \\
\text { Foundation, State Welfare Organization, Social Security Organization, Iran Health Insurance Organization, } \\
\text { Civil Servants Pension Organization, Media, Statistical Center of Iran, Real Estate and Transaction Registration } \\
\text { Center, Ministry of Communication and Information Technology, Exarchates *, Governates *, Sheriffdoms *, } \\
\text { Provincial Offices of Ministry of Cooperative, Labor and Social Welfare, Provincial Offices of Imam Khomeini Relief } \\
\text { Foundation, Provincial Offices of State Welfare Organization, Relief Centers **, Social Support Clinics ***, Vice } \\
\text { President of Planning and Strategic Supervision }\end{array}$ \\
\hline Supply & Chain Stores, Consumer Cooperative Unions, Food Retailers and Distribution Companies, Food Producers \\
\hline e-Payment & TOSAN, Payment Service Providers, SHAPARAK \\
\hline NGOs & Al-Gadir Foundation \\
\hline Target group & Low-income households who are supported by IKRF and SWO as the NFAP's recipients \\
\hline
\end{tabular}

IRKF: Imam Khomeini Relief Foundation; NGOs: non-governmental organization; SWO: State Welfare Organization.

* Institutions responsible for managing the country's divisions;

** Local centers affiliated with Imam Khomeini Relief Foundation to provide services;

*** Local centers affiliated with State Welfare Organization to provide services.

\section{Data collection}

In total, 27 face-to-face semi-structured interviews with key informants (November 2018-March 2019) were conducted. An e-mail was sent to the selected key informants, which included a brief introduction about the research and its aims, expectations from the participants, and a consent form to be signed.

Based on the study topic and literature, an interview guide was prepared, including questions about participants' involvement in the formulation and implementation of the NFAP, interactions with other stakeholders, and perception regarding their influence on the program. Due to the large number of stakeholders in the information group, most semi-structured interviews were conducted in this group. Among 32 stakeholders or their counterparts, five were not interested to participate in the study (Table 1). The interviews lasted one hour - on average, and were digitally recorded and transcribed verbatim. Moreover, secondary data were collected, regarding the roles and contributions of several stakeholders in the program from the MCLSW, SWO, IKRF, and other ministries and data sources and scrutinized them. 
Table 1

Interviewed representatives of the stakeholder groups.

\begin{tabular}{lccc}
\hline Stakeholder group & $\begin{array}{c}\text { Number of people } \\
\text { interviewed }\end{array}$ & Male & Female \\
\hline Policy & 7 & 5 & 2 \\
Credit * & 0 & 0 & 0 \\
Information & 14 & 9 & 5 \\
NGOs & 1 & 1 & 0 \\
Supply & 4 & 4 & 0 \\
e-Payment & 1 & 0 & 1 \\
Target group & 0 & 0 & 0 \\
Total & 27 & 19 & 8 \\
\hline
\end{tabular}

NGOs: non-governmental organization.

* No one in the credit group accepted to be interviewed or provided any information.

\section{Data analysis}

The transcriptions were reviewed for full conformity with the audio files. The overall approach included reviewing each interview and assessing the role and level of involvement of the participant(s) in the program. Stakeholder groups, as aforementioned, were used to identify similarities in their views, roles, and positions in relation to the program or how they affected it or how they had been affected.

According to Mitchell's theory, stakeholders' attributes were assessed based on the nature of the communications and interactions described by the participants. This information was completedwith secondary data when possible, including description of institutions' legal assignments and programrelated formal documents. A top-down analytical categorizations approach was used, in which stakeholders' classification was performed by those conducting the analysis based on their observations of the phenomenon ${ }^{4}$. Accordingly, stakeholders were categorized into three classes and six sub-classes: "latent" stakeholders are those possessing only one of the three attributes and include dormant, discretionary, and demanding stakeholders; "expectant" stakeholders are those possessing two attributes, and include dominant, dependent, and dangerous stakeholders; and "definitive" stakeholders are those possessing all three attributes (Figure 1).

\section{Ethical considerations}

The study protocol was approved by the Ethical Committee of the National Nutrition and Food Technology Research Institute (n. IR.SBMU.NNFTRI.REC.1397.049).

\section{Results}

\section{Stakeholder engagement in NFAP development and implementation}

Most interviewees in the policy group emphasized the interaction between the MCLSW, as the main trustee of NFAP, and the representatives of public and private sectors. However, the results showed that the interactions were not adequate and some relevant potential stakeholders, including academia, food and nutrition research centers - e.g., Iranian National Nutrition and Food Technology Research Institute (NNFTRI) - and office for nutrition improvement and services in the Iranian Ministry of Health were completely excluded from the formulation and implementation phases of the program, 


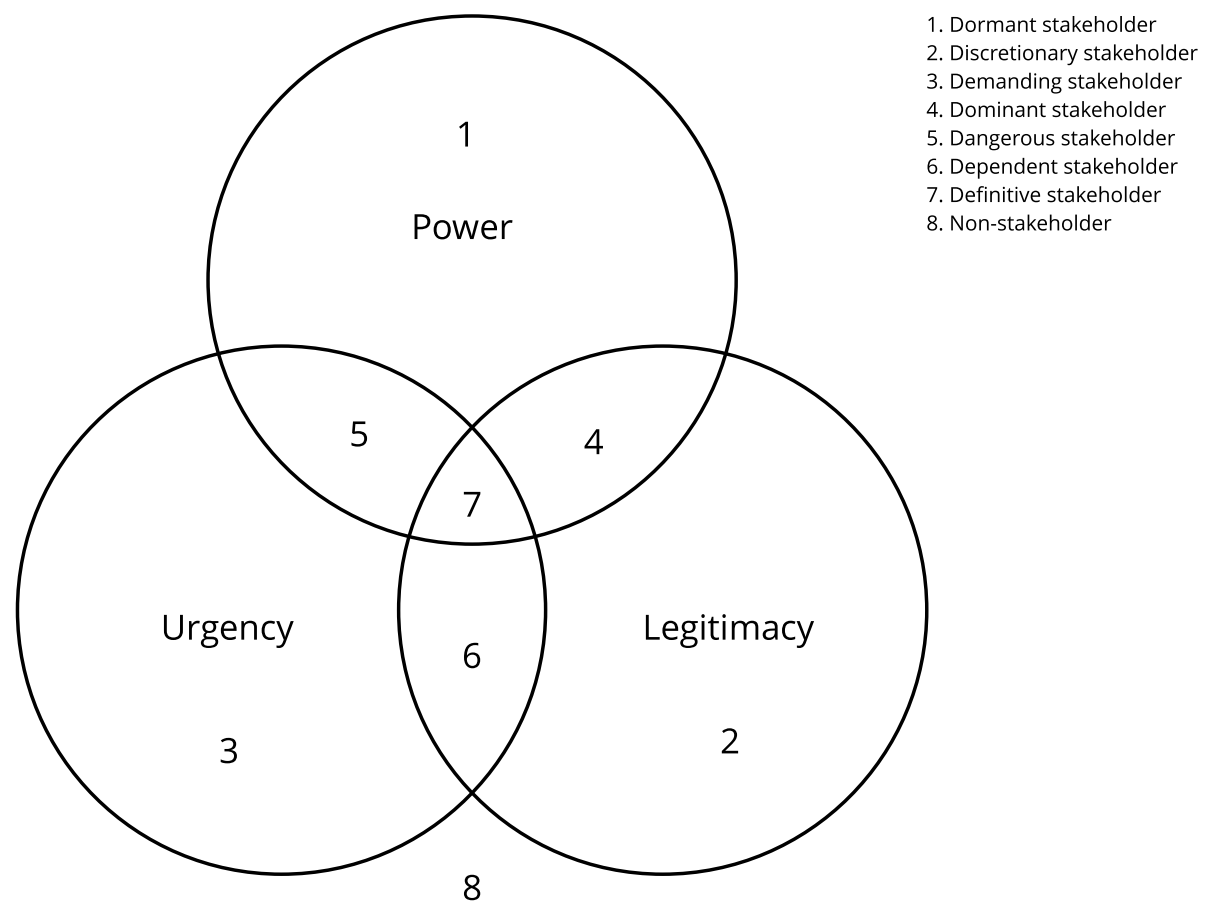

despite their ability to conduct backup research or provide technical assistance. No roles or formal mechanisms have been defined for aforementioned stakeholders' participation in the official documents of the NFAP, while a history of their interaction and cooperation in other programs has been available. Based on the findings, lack of obligation or willingness to receive technical assistance outside of the welfare domain, difference in priorities of the decision makers and academia, nature of essential information, and political priorities depending on social and economic conditions were the main reasons for limiting those stakeholders participation:

"We didn't have much communication [with academia or research centers]. Now, that the head of the working groups and our experts are generally university graduates [they have university degrees]... If it is needed, they'll ask their professors for help... This need is probably less than before" (A policy stakeholder).

"In fact, disagreements cause damage instead of helping... they would have a series of concerns, different from ours... thus we may have encountered a problem somewhere" (Another policy stakeholder).

Broad role of MCLSW in decision-making, leadership, oversight, coordination, data aggregation, and eligibility assessment in the program indicated high priority given to its claim compared to other stakeholders:

"In my opinion, the Ministry of Welfare is the main core and the rest are just partners... They make decisions and we're just doers" (An information stakeholder).

In official documents of the NFAP, institutions in the credit group were in charge of providing and allocating primary resources. Considering reliance of the NFAP on oil revenues, these stakeholders had utilitarian power 9 . Unfortunately, more detailed information was not obtained due to the time constraints or excessive conservatism of credit group's stakeholders. Most entities in the information group have been engaged in providing required information for the Deputy of Welfare in MCLSW in a one-sided mode. Based on legal documents, this information included income, car ownership, estate 
and property, stock market assets, postal code, national code, household size, communication data, traveling abroad, insurance, and detailed information on vulnerable persons in supportive organizations. As stated by one of the stakeholders in information group, supportive organizations, including IKRF and SWO, should be more involved in the program considering their access to detailed information about living conditions of the clients:

"We are aware of the living conditions of each of recipients [in State Welfare Organization]. Therefore, we are the best resource to inform the authorities about the situation of the poorest families and to uncover the reasons. We feel and understand the causes of all the problems that the clients have" (Another information stakeholder).

According to the NFAP legal documents in the formulation phase, deputy minister of welfare in MCLSW signed formal contracts with 12 distribution agents, which had the most prestigious and extensive networks in Iran. Chain stores, consumer cooperative unions, food retailers, and distribution companies were directly involved in the program. Their critical role in the supply chain has given them managerial attention and a good position in terms of power and influence on the program:

"We as an arm of the government, we distribute goods, as a form of distribution of social justice that the government intended. We have a pivotal role in it... We have a database [he pauses, as if he hesitate to open up] where our customers' purchases are completely recorded; we analyze their daily, monthly, and periodic purchases. [It is clear] what items they buy?".

MCLSW formally cooperates with two companies - TOSAN and SHAPARAK - as management reference of integrated electronic payment in Iran and also seven payment service providers (PSPs) to provide an electronic platform and payment in the NFAP. Due to key role of electronic payment system in the program implementation, periodic meetings are held to coordinate actions with relevant representatives at Deputy of Welfare. On the other hand, only one NGO, Al-Ghadir Foundation, has been formally involved in the program implementation. It was one of the three channels for guiding program's recipients, as well as, collecting and transmitting their problems to the NFAP's trustees. The other ways were visiting experts in MCLSW and using the USSD system (Unstructured Supplementary Service Data): "We only communicate with the Ministry of Welfare... When a person who has been removed from the list is now eligible, we recommend them to refer to the relevant institution, for example the individuals' social worker, to add their name onto the list [for support] in the next period. We will guide them in this way".

Generally, we did not found effective and defined cooperation between NGOs active in the field of food and nutrition, and other counterparts in both formulation and implementation of the NFAP:

"NGOs have no role... collaboration with NGOs have been postponed. We believe that NGOs can help identify those who are eligible but have not been covered by IKRF and SWO. As a result, other people who really deserve support would be recognized... but this case was postponed" (A policy stakeholder).

\section{Stakeholders' salience in NFAP}

The classification of stakeholder based on the aggregation of three characteristics (power, legitimacy and urgency) enabled the identification of six sub-classes of stakeholders in the NFAP. This result suggests that each stakeholder has different positions and spheres of influence regarding the attracting decision-makers' attention.

Al-Ghadir foundation, charities, target group, and international organizations were latent. Since Al-Ghadir foundation held just legitimacy of the three attributes, it was categorized as "discretionary" (Figure 2). The others groups, including charities, target groups, and international organization -depending on the type of attributes they showed - were classified as "dormant" and "demanding" stakeholders, respectively. Public managers may do nothing about stakeholders, who they believe have only one of the identifying attributes. This occurs because of limited time, energy, and other resources to track the stakeholder's behavior and to manage these varied relationships 9 . Public managers may also fail to recognize those stakeholders' existence. Similarly, the latent stakeholders in this program may not be given any deserved attention or acknowledgement. For example, despite having financial power to impose their will on policy-makers, charities' power remains unused due to the lack of a legally defined role (here legal legitimacy) or immediate claim. 
Figure 2

Stakeholder groups and potential stakeholders are classified according to possession or attributed possession of power, legitimacy and urgency (Mitchell's Theory 9) in Iran's National Food Assistance Program (NFAP).

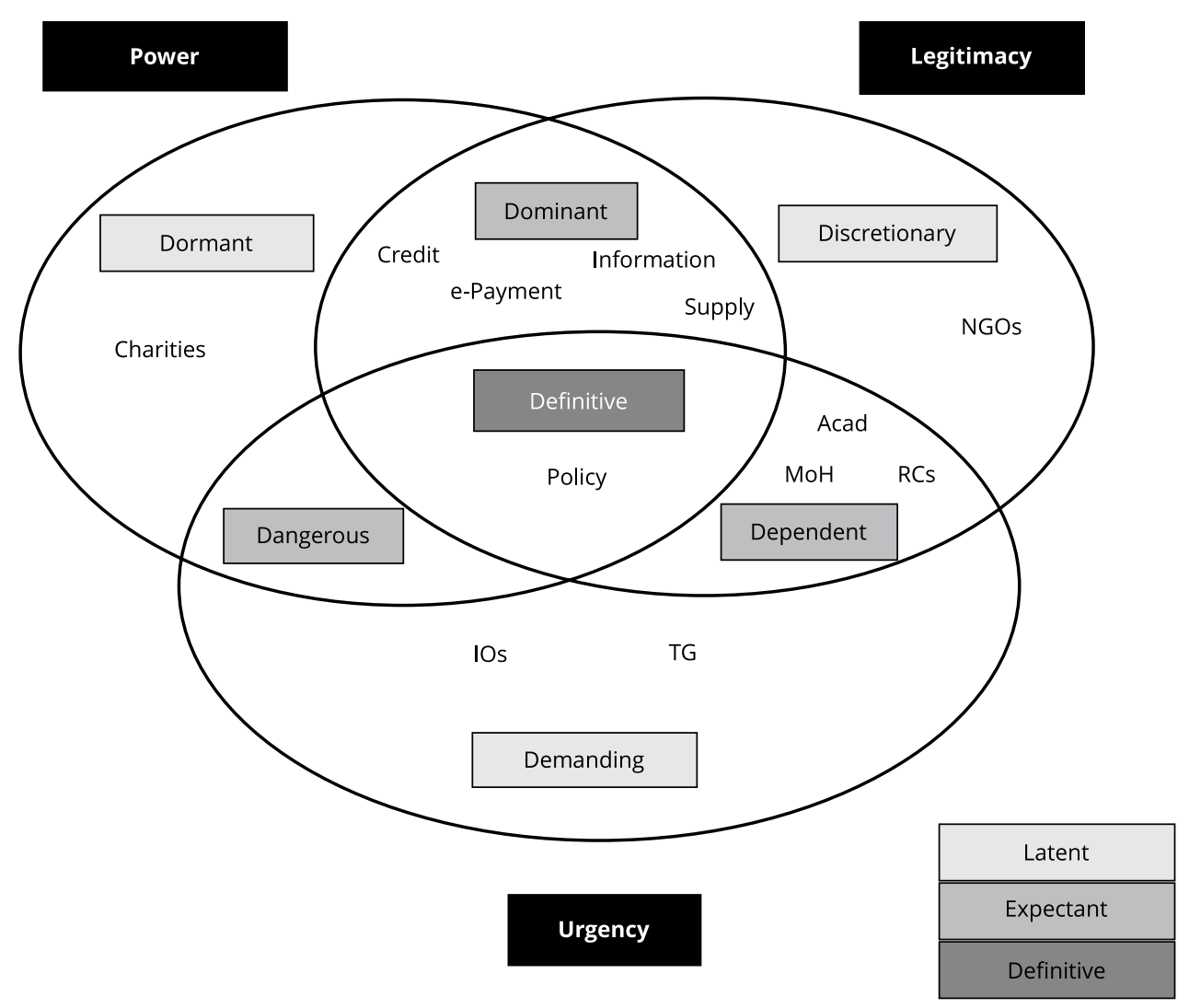

Acad: academia; ; IOs: international organizations; MoH: Iranian Ministry of Health; NGOs: non-governmental organizations; RCs: research centers; TG: target group.

Note: policy group emanated as the definitive stakeholder in its interactions with program decision makers.

Information, credit, supply, and e-Payment stakeholders with possession of power and legitimacy, comprised the "dominant" group and were classified as a subclass of the "expectant" stakeholders. While other expectants, including academia, food and nutrition research centers, and Iranian Ministry of Health as "dependent", held legitimacy and urgency. By analyzing (potential) relationships between decision makers and expectant stakeholders, it can be highlighted the change in movement that characterizes this class. The combination of two attributes (power and legitimacy or legitimacy and urgency) leads to an active versus passive positioning of such stakeholders, and galvanizes their interaction to a higher level than the latent class 9 . We did not find any stakeholders who could be categorized as "dangerous" since none had both power and urgency (Box 2).

The policy groups placed at the highest level of salience and importance in stakeholders' classification suggests that different sources of power (here coercive and utilitarian), legitimacy (legal type), and urgent claims have been provided for these institutions including MCLSW, MIMT and MAJ. 
Box 2

Power, legitimacy and urgency in the interactions reported between stakeholder groups and decision makers in Iran's National Food Assistance Program (NFAP).

\begin{tabular}{|c|c|c|c|c|}
\hline STAKEHOLDER (ACTUAL/POTENTIAL) & $\begin{array}{l}\text { EVIDENCE } \\
\text { OF POWER }\end{array}$ & $\begin{array}{l}\text { SOURCE OF } \\
\text { LEGITIMACY }\end{array}$ & URGENCY & $\begin{array}{c}\text { NATURE OF RELATIONS BETWEEN THE } \\
\text { STAKEHOLDER GROUP AND PROGRAM } \\
\text { DECISION MAKERS }\end{array}$ \\
\hline Policy & $x *$ & $x * *$ & $x$ & $\begin{array}{c}\text { Use of coercive tactics based on legal } \\
\text { documents, legal legitimacy to coordinate } \\
\text { processes and monitor program } \\
\text { implementation }\end{array}$ \\
\hline Credit & $X * \star \star$ & $X * \star$ & - & $\begin{array}{l}\text { Acknowledged importance of relationship, } \\
\text { close interaction with formal mechanisms; } \\
\text { impact on the program }\end{array}$ \\
\hline Information & $X \star \star \star$ & $X * \star$ & - & $\begin{array}{l}\text { Acknowledged importance of relationship, } \\
\text { close but unilateral interaction }\end{array}$ \\
\hline NGOs & - & $X \#$ & - & $\begin{array}{c}\text { Limited attention or acknowledgment, } \\
\text { limited interaction, dependent upon formal } \\
\text { participation }\end{array}$ \\
\hline Supply & $X \star \star \star$ & $X * \star$ & - & $\begin{array}{l}\text { Acknowledged importance of relationship, } \\
\text { formal interactions, direct impact on goods } \\
\text { availability }\end{array}$ \\
\hline e-Payment & $X * \star \star$ & $x * \star$ & - & $\begin{array}{c}\text { Acknowledged importance of relationship, } \\
\text { limited and technical interactions, legal } \\
\text { legitimacy of participation }\end{array}$ \\
\hline Research centers \#\# & - & $X * \star$ & $x$ & $\begin{array}{c}\text { No need to interact, limited } \\
\text { acknowledgment, no impact on the } \\
\text { program }\end{array}$ \\
\hline Academia \#\# & - & X\#\#\# & $x$ & $\begin{array}{c}\text { No interaction, conflicting priorities, } \\
\text { limited acknowledgment, no impact on the } \\
\text { program }\end{array}$ \\
\hline $\begin{array}{l}\text { Ministry of Health (Community Nutrition } \\
\text { Office) \#\# }\end{array}$ & - & $X * \star$ & $\mathrm{X}$ & $\begin{array}{c}\text { No need to interact, limited } \\
\text { acknowledgment, no impact on the } \\
\text { program }\end{array}$ \\
\hline International organizations \#\# & - & - & $x$ & $\begin{array}{l}\text { No interaction, generally ignored, doubtful, } \\
\text { no impact on the program }\end{array}$ \\
\hline Target group \#\# & - & - & $x$ & $\begin{array}{l}\text { Very limited or indirect interaction, ignored, } \\
\text { no impact on the program }\end{array}$ \\
\hline Charities \#\# & $X * \star \star$ & - & - & $\begin{array}{c}\text { No interaction, unused power, limited } \\
\text { acknowledgment }\end{array}$ \\
\hline
\end{tabular}

NGOs: non-governmental organization.

* Coercion: abhorrent tactics, violence or force (strikes, threats);

** Legal-based on the law or contract (potentially allocable to academia, international organizations);

$\star \star \star$ Utilitarian: material or financial means (goods, services) (potentially allocable to research centers, academia, Ministry of Health, international organizations and charities);

\# Property-based-rights of (shared) ownership (potentially allocable to international organizations, NGOs);

\#\# Potential stakeholder;

\#\#\# Moral: considered right or accepted behavior. 


\section{Discussion}

Based on the findings, we identified three stakeholders' characteristics: (1) latent stakeholders and opportunities; (2) expectant stakeholders and stabilizing their situation and; (3) definitive stakeholders and their privileged position.

\section{Latent stakeholders and opportunities}

For the dynamic nature of the policy-maker-stakeholder relationship, latent stakeholders may achieve superiority by gaining legitimacy or urgency and improving program implementation. Philanthropy activities in community have been recognized as development factor to leverage their resources, networks, and expertise - especially regarding the private sector ${ }^{23}$. Although charities within the NFAP operations lack any defined interactions with other stakeholders, decision makers must be aware of the existence of such stakeholders, considering their potential to acquire a second attribute. Charity funding has been the backbone for a large number of projects 24 , moreover, if well organized, their ability to be policy advocate is significant 24,25 . Charities may engage with candidates or representatives of political parties to lobby, to debate, or to seek explanation of policies relevant for their purposes. They may also assess and critique policies 25 .

Weak presence of NGOs means that although such stakeholders have legitimacy (moral type), they lack immediate claim or power to influence. In the absence of those attributes, policy-makers (or public managers) do not feel any pressure to engage them in an active relationship. Whereas, NGO's role in alleviating food insecurity has been shown in different settings 26 . Due to their on-the ground work with food insecure individuals, organizing and participating NGOs in this program can be very helpful in providing data, completing the database of the most vulnerable groups and increasing access to them. Moreover, their role will be crucial in undertaking research on existing gaps and educating marginalized populations. According to Maslow 27, food is one of the most basic needs and therefore responses to the beneficiaries' food insecurity would be urgent 4 . The right to adequate food as a basic human right was first recognized in the Universal Declaration of Human Rights in 1948, as part of the right to a adequate standard of living (Art. 25) and has been emphasized by the United Nations 28 . Over the past decade, several governments have shown strong commitment and support towards achieving the right to adequate food. The Brazilian Cooperation Agency led efforts towards establishing sustainable School Feeding Programs within the context of human right to food 29,30. These efforts are built around strong coordination between sectors of governments, strengthening of institutional capacities and creation of conducive legal frameworks 31 . This successful experience is reminiscent of that embedding policy in regulation is important, but does not always protect it from changes in government, politics and/or funding. Linking policy to fundamental rights, and gaining support from a variety of stakeholders - including citizens - is essential to protect economic, social, and cultural rights 31 . Unfortunately, in Iran, law, policy-making and cultural norms as manifestations of abstract institutions have not yet been adapted to protect the right to food. The Federal Government focuses on food policies aimed at improving Iranians' food security, which has no legal basis for restoration compared to the concept of the right to food. As a result, the capacity or ability of different institutions to perform their functions and achieve effective collaboration is not supported with sufficient commitment to achieve this common goal. Mexico has also been a driving force behind the Hunger-Free Mesoamerica program that puts forth innovative development solutions to guarantee decent living conditions for the most vulnerable population 32,33. Moreover, the country has been essential to support and to increase the role and impact of parliamentarians in the fight against hunger, notably through its support to regional efforts of Parliamentary Fronts against Hunger and Malnutrition in Latin America and the Caribbean 34,35.

The position of the target group (NFAP's recipients) and related international organizations as demanding stakeholders suggests that if they are unable or unwilling to acquire power or legitimacy to transfer their claim to a superior position, urgency of their claim will be insufficient to apply. Note that, despite close cooperation occurred in the past, the presence and participation of international organizations is currently not welcomed in the NFAP due to the suspicion or possibility of espionage or a misuse of local information (as clearly noted by some experts in the MCLSW). Trust-building is 
one of the most significant components to produce a virtuous cycle of collaboration 36,37. Therefore, it seems necessary to eliminate such misunderstandings and to provide conditions for benefiting from their experiences, financial, and technical aid in this program. Also, apparently the most accessible source of legitimacy for target group is a moral type - attendance of the recipients representatives in the NFAP's meetings for reflecting their needs. The communities may assist to define some of the program objectives by a participatory decision-making process 38. Preliminary efforts including assessment of community decision-making structures, analysis of existing community support mechanisms, and public participation and education are necessary 38,39. The best example of such arrangement is the experience of Brazil. The National Conference on Food and Nutrition takes place every four years, and is one of the most important expressions of citizen participation in Brazil's food policy, as it approves the guidelines and priorities for the National Food and Nutrition Security Policy and its Annual Plan. The event is preceded by regional and municipal conferences throughout all 27 states of Brazil 31. The relevance of the mentioned issue in our study is that if target groups cannot obtain legitimacy to legally influence, the target group may tend to coercive power such as protest and violence, changing its position to dangerous stakeholders. Research has also shown that when food insecurity issues are not addressed, civil and political rest is likely as was seen in the Arab spring during the 2009 food price hikes 40,41. However, in the current program, no stakeholder was identified as dangerous stakeholder with possibility of illegal use of power to draw attention to immediate claims.

\section{Expectant stakeholders and stabilizing their situation}

Definite roles of dominant stakeholders in legal documents of the NFAP has made their expectations important to decision makers. In a similar study by Saint Ville et al. 14 that assessed the configuration of relations and interactions between national stakeholders and smallholder farmers in national food security policy development in the Caribbean, credit group had the same position but policy, research, external assistance, or even NGOs were located in different classes by this approach. Difference in context, level of stakeholders' engagement and defined formal roles can be justifiable. In a study performed by Sonnino et al. 42 on the school feeding program in Brazil, it was shown that as the state continued to reconfigure its relationships with food producers, civil society and the market, new relational learning processes were occurring. However, in this study, some missing voices in these spaces of deliberation was found.

The position of institutions (potentially) such as the Irnanian Minsutry of Health, academia, and research centers regarding food security in the subclass of dependent stakeholders indicates these stakeholders - due to lack of power - depend on other stakeholders or decision-makers to apply their legal and immediate claims. Lack of a definition or any legal and official role for the mentioned institutions, probably indicates that decision makers have mostly focused on mechanisms or standards related to assessing financial eligibility of recipients and their accessibility to the program. While better matching of types and amounts of available foods to the actual need of recipients and other related issues concern the timing - i.e., the frequency - of allotments are domains that scientific consultants could play a critical role 43. Probably, the salience for those marginalized stakeholders could be attained through advocacy or guardianship of other powerful stakeholders or establishing legal and moral legitimacy. Considering the dynamics of this model, it is possible to transfer these dependent stakeholders into definite class with the highest advantage. Urgency associated with legitimacy promotes access to decision-making channels 9 .

\section{Definitive stakeholders and their privileged position}

Definitive stakeholders have taken advantage of legal documents and assignments in the program as a tool to attract cooperation from several stakeholders. According to Weber's idea, power and legitimacy combined, constitute authority (legitimate use of power) 44 . However, mere attention to them or not addressing "urgency" does not make the model dynamic. Urgency exists only when two conditions regarding a relationship or claim are met: (1) being time-sensitive in nature and (2) being important or critical to the stakeholder(s) 11,17. According to Cobb \& Elder justification for the significance of symbols role 45 , it can be argued that food security, as a symbol of national security, plays 
a critical role in creating urgency - achieving food security is an international priority. The urgent need to address global food security is rightly recognized in the UN Sustainable Development Goals (SDGs) 46. Thus, policy group in the NFAP - due to their legal and related role in providing food security - have urgency in claim and taking action.

Note that, each of the three attributes is variable and does not have a fixed state, varying for each specific institution or relationship 9,18. Moreover, existence or degree of existence for each of these characteristics result from multiple and socially constructed perception rather than a reality 17 . On the other hand, individuals or institutions may not be aware of those attributes or may not intend to display any implicit behavior. "Power gains authority through legitimacy, and it gains exercise through urgency" 9 (p. 869), but, first of all, use of power and legitimacy requires stakeholders' awareness of the ir existence of this aspects as well as desire to use them. Thus, it is essential that marginalized stakeholders be aware of the fact that power and legitimacy - such as importance in policymaker's view - are dynamic and can be both lost and acquired by various means, such as coalition building, political action, and social construction of the reality. Also, decision makers should be constantly aware of constantly changing positions, amount and type of attention that should be given to different stakeholders. The understanding of this fact is essential to determine the allocation of organizational resources in response to different and rising stakeholders' demands and possibly project outcomes. Such understanding will facilitate and enhance the possibility of "boundary" organizations serving as champions, knowledge exchange and learning, and greater trust among stakeholders during the food and nutrition policy process.

\section{Strengths and limitations of the study}

By considering marginalized and powerless stakeholders in the NFAP, we tried to reduce the risk of bias that may be created, since we are dealing with usual stakeholders and less representation of potential groups. Moreover, contrary to usual approaches at this level of analysis, data were obtained through interviews with direct participation of stakeholders and understanding their own power and capacity to influence the program. It will provide an opportunity to use knowledge and perspectives of those stakeholders in anticipating potential problems related to resources and innovative opportunities for program management.

Lack of participation of credit group in the interviews was a significant limitation of this study. We tried to obtain necessary information with other interviews and secondary data. Also, the lack of studies conducted with this managerial perspective in the field of food and nutrition limited our analysis, that is, we could not compare our findings with similar studies.

\section{Conclusion}

In conclusion, this was focused on the dynamics from Mitchell's stakeholder salience theory and provided evidence for understanding how to gain or lose salience of stakeholders from the policymakers' point of view. The policy group - and to a lesser extent, the information, credit, supply, and e-Payment groups - succeeded in attracting the attention of policy-makers and had the most power and legitimacy to impose their will on the program. Despite identifying some significant stakeholders - such as Ministry of Health, academia, food and nutrition research centers, target group, charities, and international organizations based on their characteristics - policymakers did not have a clear understanding of their positions, thus, they have been ignored and have little formal chance to affect the program and some of them (target group) have only been affected. We hope that awareness and perception towards current position of those institutions along with providing a context for managerial attention will change the position and delegate resources to play a more effective role and improve participation in the program. Otherwise, it would seem that long-term viability and support for the program will be jeopardized with inevitable declines in its effectiveness and legitimacy. 


\section{Contributors}

M. Pourghaderi participated in the conceptualization and design of the study, acquisition, analyses and interpretation of data and drafting the first version of the manuscript. N. Omidvar and A. Takian supervised the process and participated in the conceptualization and design of the study, interpretation of data and critically reviewing the manuscript. A. Saint Ville participated in design, interpretation of data and drafting the paper. H. M. Kangarani and $\mathrm{H}$. Eini-Zinab contributed to the interpretation of data and critically reviewing the manuscript. All authors are responsible for all aspects of the study, including ensuring its accuracy and integrity.

\section{Additional informations}

ORCID: Mona Pourghaderi (0000-0002-34672468); Nasrin Omidvar (0000-0001-7305-0461); Amirhossein Takian (0000-0001-7806-5558); Arlette Saint Ville (0000-0001-8951-8188); Hannaneh Mohammadi Kangarani (0000-0002-39985658); Hassan Eini-Zinab (0000-0002-6895-034X).

\section{Acknowledgments}

The authors would like to thank Dr. Ahmad Meidari; Deputy Minister of Welfare at the Iranian Ministry of Cooperative, Labor and Social Welfare and all experts who participated and collaborated with interviews and data collection (Grant/Award number: IR.SBMU.NNFTRI.REC.1397.049).

\section{References}

1. Brouwer H, Woodhill J, Hemmati M, Verhoosel K, Vugt S. The MSP Guide: how to design and facilitate multi-stakeholder partnerships. Wageningen: Practical Action; 2016.

2. Duncan J, Claeys P. Politicizing food security governance through participation: opportunities and opposition. Food Secur 2018; 10:1411-24.

3. Freeman RE. Strategic management: a stakeholder approach. 2nd Ed. New York: Cambridge University Press; 2010.

4. Reed MS, Graves A, Dandy N, Posthumus H, Hubacek K, Morris J, et al. Who'S in and why? A typology of stakeholder analysis methods for natural resource management. J Environ Manage 2009; 90:1933-49.

5. Quick KS, Bryson JM. Public participation. In: Ansell CH, Torfing J, editors. Handbook on theories of governance. Cheltenham: Edward Elgar Publishing; 2016. p. 158-69.
6. Rajan D, Mathurapote N, Putthasri W, Posayanonda T, Pinprateep P, Courcelles S, et al. Institutionalizing participatory health governance: lessons from nine years of the National Health Assembly model in Thailand. BMJ Glob Health 2019; 4 Suppl 7:e001769.

7. Poto MP, Fornabaio L. Participation as the essence of good governance: some general reflections and a case study on the arctic council. Arctic Review on Law and Politics 2017; 8:139-59.

8. Brugha R, Varvasovszky Z. Stakeholder analysis: a review. Health Policy Plan 2000; 15: 239-46.

9. Mitchell RK, Agle BR, Wood DJ. Toward a theory of stakeholder identification and salience: defining the principle of who and what really counts. Acad Manage Rev 1997; 22:853-86. 
10. Oliveira Neto GC, Godinho Filho K, Devos Ganga GM, Costa BK. Exploring stakeholder salience for the adoption of principles and tools of cleaner production in Brazilian companies. Revista Brasileira de Gestão de Negócios 2015; 17:932-58.

11. Hall M, Millo Y, Barman E. Who and what really counts? Stakeholder prioritization and accounting for social value. Journal of Management Studies 2015; 52:907-34

12. Loosemore M, Raftery J, Reilly C, Higgon D. Risk management in projects. 2nd Ed. Abingdon: Taylor and Francis; 2006.

13. Miragaia DAM, Ferreira J, Carreira A. Do stakeholders matter in strategic decision making of a sports organization? RAE Revista de Administração de Empresas 2014; 54:647-58.

14. Saint Ville AS, Hickey GM, Phillip LE. How do stakeholder interactions influence national food security policy in the Caribbean? The case of Saint Lucia. Food Policy 2017; 68: 53-64.

15. Yin RK. The abridged version of case study research: design and method. In: Bickman L, Rog DJ, editors. Handbook of applied social research methods. $5^{\text {th }}$ Ed. London: SAGE Publications; 2014. p. 229-43.

16. Ylikoski P, Zahle J. Case study research in the social sciences. Studies in History and Philosophy of Science Part A 2019; 78:1-4.

17. O'Higgins ER, Morgan JW. Stakeholder salience and engagement in political organisations: who and what really counts? Society and Business Review 2006; 1:62-76.

18. Boesso G, Kumar K. Who or what really counts in a firm's stakeholder environment: an investigation of stakeholder prioritization and reporting. ("Marco Fanno" Working Paper, 51). https://economia.unipd.it/sites/economia. unipd.it/files/20070051.pdf (accessed on 10/ May/2021).

19. Seed B, Lang T, Caraher M, Ostry A. Integrating food security into public health and provincial government departments in British Columbia, Canada. Agric Human Values 2013; 30:457-70.

20. Breeman G, Dijkman J, Termeer C. Enhancing food security through a multi-stakeholder process: the global agenda for sustainable livestock. Food Security 2015; 7:425-35.

21. Food and Agriculture Organization; World Food Program. Monitoring food security in countries with conflict situations: a joint FAO/WFP update for the United Nations Security Council. https://docs.wfp.org/api/ documents/WFP-0000107208/download/ ?_ga $=2.259346186 .142084532 .15959623241$ 089478469.1592078998 (accessed on 14/Apr/ 2020).

22. Noy C. Sampling knowledge: the hermeneutics of snowball sampling in qualitative research. Int J Soc Res Methodol 2009; 11: 327-44.
23. Stringer J. Philanthropy as a development actor: influence and implications. http://devpol icy.org/2017-Australasian-AidConference/ Papers/Stringer_Philanthropy _as_develop ment_actor.pdf (accessed on 03/Apr/2020).

24. Furbank L. Foundations supporting food projects around the world. https://www. nycfoodpolicy.org/11509-2 (accessed on 14/ Apr/2020).

25. Lawyer AE. Third dimension - the political advocacy of charities - what is allowed and what isn't. https://www.millsoakley.com.au/ thinking/third-dimension-the-political-advo cacy-of-charities-what-is-allowed-and-whatisnt (accessed on 13/Apr/2020).

26. Nyamu IK. The role of NGOs in alleviating food insecurity in Makindu and Kibwezi divisions, Makueni district, Kenya [Doctoral Dissertation]. Nairobi: Kenyatta University; 2003.

27. McLeod S. Maslow's hierarchy of needs. https://www.craigbarlow.co.uk/_webedit/ uploaded-files/All\%20Files/Risk/simplypsy chology.org-Maslows\%20Hierarchy\%20of\%20 Needs.pdf (accessed on 21/Jul/2020).

28. Claeys P, Frison C. Right to food in international law. In: Thompson PB, Kaplan DM, editors. Encyclopedia of food and agricultural ethics. Dordrecht: Springer Science; 2014. p. 1617-23.

29. Sidaner E, Balaban D, Burlandy L. The Brazilian school feeding programme: an example of an integrated programme in support of food and nutrition security. Public Health Nutr 2013; 16:989-94.

30. Pye-Smith C. Scaling up the Brazilian school feeding model. Rome: Food and Agriculture Organization; 2014.

31. Santarelli M, Marques Vieira L, Constantine J. Learning from Brazil's food and nutrition security policies. Falmer: Institute of Development Studies; 2018.

32. Jusidman-Rapoport C. The right to food as a human right. Salud Pública Méx 2014; 56 Suppl 1:86-91.

33. Onorati AWB, Mattheisen E. Right to food and nutrition watch. Berlin: Bread for the World; 2017.

34. Food and Agriculture Organization. Parliamentary fronts against hunger, and legislative initiatives for the right to adequate food and nutrition. Rome: Food and Agriculture Organization; 2017

35. Food and Agriculture Organization. Right to food in the cities: focus on Mexico legislation. http://www.fao.org/3/a-ap558e.pdf (accessed on $12 / \mathrm{Jun} / 2020$ ).

36. Ansell C, Gash A. Collaborative governance in theory and practice. Journal of Public Administration Research and Theory 2008; 18: 543-71. 
37. Lubell M. Collaborative partnerships in complex institutional systems. Current Opinion in Environmental Sustainability 2015; 12:41-7.

38. Food and Agriculture Organization. Targeting for nutrition improvement, resources for advancing nutritional well-being reference guide. Rome: Food and Agriculture Organization; 2001.

39. Chirenje LI, Giliba RA, Musamba EB. Local communities' participation in decision making processes through planning and budgeting in African countries. Chinese Journal of Population Resources and Environment 2013; 11 : 10-6.

40. Luciani G. Combining economic and political development: the experience of MENA. Leiden: Brill Nijhoff; 2017.

41. Babar Z, Kamrava M. Food security and food sovereignty in the Middle East. Oxford: Oxford Scholarship Online; 2014.

42. Sonnino R, Torres CL, Schneider S. Reflexive governance for food security: the example of school feeding in Brazil. Journal of Rural Studies 2014; 36:1-12.
43. Oliveira V, Prell M, Tiehen L, Smallwood D. Design issues in USDA's supplemental nutrition assistance program: looking ahead by looking back. Washington DC: Economic Research Service Economic, United States Department of Agriculture; 2018. (Research Report, 243)

44. Parsons T. The theory of social and economic organization. 2nd Ed. New York: The Free Press; 2009.

45. Linklater A. Symbols and world politics: towards a long-term perspective on historical trends and contemporary challenges. European Journal of International Relations 2018; 25:931-54.

46. Pérez-Escamilla R. Food security and the 2015-2030 sustainable development goals. From human to planetary health: perspectives and opinions. Curr Dev Nutr 2017; 1:e000513. 


\section{Resumo}

Os processos com múltiplos atores (multi-stakeholder), como parte necessária do desenvolvimento de políticas públicas, podem ajudar a reunir perspectivas diversas para informar e melhorar as politicas de segurança alimentar. O Programa Nacional de Assistência Alimentar do Irã (NFAP) é um dos maiores programas de bem-estar social no Irã, e que fornece apoio a famílias de baixa renda para reduzir a insegurança alimentar. $O$ estudo teve como objetivo identificar e categorizar os atores atuais e potenciais envolvidos no NFAP, usando o modelo de stakeholder salience). De acordo com a teoria de Mitchell, os atributos (poder, legitimidade e urgência) foram avaliados com base na natureza de suas interações, papeis e níveis de engajamento. Os resultados revelaram uma série de atores importantes, porém marginalizados, incluindo o Ministério da Saúde do Irã (Divisão de Melhoria Nutricional Comunitária), academia, centros de pesquisas em alimentação e nutrição, grupo-alvo, filantropias e organizações internacionais, que não receberam nenhuma atenção institucional dirigida ou prioritária quanto às suas demandas. O desequilíbrio da atenção prestada a alguns dos grupos interessados, caracterizados como "definitivos" e "dominantes", ignorando outros atores importantes, irá prejudicar a viabilidade no longo prazo e reduzir o apoio para o programa, com um declínio inevitável na legitimidade. A compreensão da mudança nas características dos atores é a principal variável na determinação da alocação dos recursos institucionais na resposta às diversas e crescentes demandas dos atores, e possivelmente dos resultados dos projetos. Tal compreensão facilitará e fortalecerá a troca de conhecimentos e lições, além de maior confiança mútua entre os atores durante o processo de politicas de alimentação e nutrição.

Participação dos Interessados; Programas de Assistência Alimentar; Políticas Públicas

\section{Resumen}

Los procesos de participación múltiple, constituyen una parte necesaria en el desarrollo de políticas públicas, puesto que pueden ayudar a presentar diversas perspectivas, así como informar y mejorar la creación de políticas públicas en seguridad alimentaria. El Programa Nacional de Asistencia Alimentaria de Irán (NFAP) es uno de los principales programas de bienestar social en Irán, que proporciona ayuda a los hogares con bajos ingresos, a fin de reducir la inseguridad alimentaria. El objetivo del estudio fue identificar y categorizar a los actuales y potenciales participantes múltiples en el NFAP, utilizando un modelo de copartícipes relevantes. Los atributos de las partes interesadas (poder, legitimidad y urgencia), según la teoría de Mitchell, fueron evaluados basados en la naturaleza de sus interacciones, roles, y nivel de implicación. Los resultados revelaron un número de copartícipes importantes, pero marginalizados, incluyendo el Ministerio de Salud de Irán (Departamento de Mejora de la Nutrición en la Población), instituciones académicas, centros de investigación de alimentación y nutrición, así como grupos objetivo, organizaciones de beneficencia, y organizaciones internacionales, que no habian recibido ninguna atención específica institucional, ni ninguna prioridad en sus reclamaciones. La atención desequilibrada, otorgada a alguno de los grupos partícipes, caracterizada como "definitiva" $y$ "dominante, e ignorando algunas otras importantes, pondrá en peligro a largo plazo la viabilidad y socavará el apoyo para el programa con su inevitable declive en términos de legitimidad. Entender el cambio en las características de los participantes es la variable principal para determinar la asignación de los recursos organizativos, en respuesta a las diferentes y crecientes demandas de los participantes, así como posiblemente a los resultados de los proyectos. Esto facilitará y acrecentará la posibilidad de intercambio de conocimiento y aprendizaje, así como una mayor confianza entre los partícipes durante los procesos de políticas alimentarias y nutricionales.

Participación de los Interesados; Programas de Asistencia Alimentaria; Políticas Públicas

Submitted on 09/Dec/2020

Final version resubmitted on 13/May/2021

Approved on 21/May/2021 